\title{
Applying User Interface Analytics to Identify Online Shop Performance Factors
}

\author{
A. Bellanov*, Y. Suharyanti, and Y. Daryanto
}

\begin{abstract}
The massive use of information systems and digital applications drives the growth of e-commerce, including online shops in marketplaces. However, some of the online shops are not successful. To improve their performance, the success factors of the online shops should be recognized. This study develops a model of online shop success factors. Unlike the other researches that use customer preference data from surveys, this study uses user interface analytics to develop the model. A marketplace operated in Indonesia was selected as the case study. The study begins with a scraping process of the data available at online shops' user interfaces in the marketplace. After data cleaning, outliers handling, and data clustering by product category, a series of multiple regression analyses are performed to get the model estimates. Eight variables are defined to develop the model, i.e., product price, percentage of responded chat, shop joining time in the marketplace, number of product types, number of raters, shop rating, shop reputation, and number of followers. The results of the multiple regression process show that the model estimate is specific for every product category. The final model can be used as a reference by the online shop sellers to develop their strategy to improve their shop performance. Moreover, the results also prove that user interface analytics is effective in estimating the performance factors of online shops in a marketplace.
\end{abstract}

Keywords: Online shop, user interface, analytics, performance factors, regression

Article Info: Received August 5, 2021; Revised September 9, 2021; Accepted September 13, 2021.

\section{INTRODUCTION}

The rapid development of information technology and the high internet usage in Industry 4.0 are emerging issues that trigger the rapid growth of e-commerce in Indonesia. Indonesia has the third-largest number of internet users in the Asia-Pacific region, after China and India (Statista, 2021a). Indonesia is predicted to have 256.37 million internet users in 2025 from 199.16 million in 2020 (Statista, 2021b). Accordingly, the ecommerce transactions in Indonesia are forecasted to be increased from 351.1 trillion rupiahs in 2020 to 707.6 trillion rupiahs in 2024 (GlobalData, 2020). Ecommerce will be the driver of economic growth in Indonesia, as well as in other countries.

Recently, the COVID-19 pandemic has encouraged people to use online activities, including shopping
(Brewer \& Sebby, 2021; Chang et al., 2021; SanchezDiaz et al., 2021). The number of visitors in three top Indonesian marketplaces increased by more than $20 \%$ in the second quarter of 2020, when the first cases of COVID-19 infections were identified in Indonesia, compared to the negative growth in the previous four quarters. Some studies about people's behavior predict that after the pandemic, there will be a new normal condition that will not be the same as the normal condition before the pandemic (Dannenberg et al., 2020; Sharma et al., 2020). Some new habits during a pandemic will lead to new habits in the post-pandemic era. Online activity is one of those new habits, including online shopping. It is interesting to discuss online shopping, as it will be the future basic need for people.

The development of e-commerce is also confirmed as one of the backbones of Indonesia's national economic

A.Bellanov* is with Department of Industrial Engineering, Universitas Atma Jaya Yogyakarta, Yogyakarta, Indonesia (email: agrientabellanov@gmail.com).

* Corresponding author 
growth, as Presidential Decree No. 74/2017 about Indonesia's e-commerce roadmap was signed by President Joko Widodo (Kementerian Hukum dan HAM RI, 2017). Some researches in some countries (Liu, 2013; Elseoud, 2014; Qu \& Chen, 2014; Falk \& Hagsten, 2015) also state that e-commerce has an important role in a country's economic development. The contribution of e-commerce in economic development, especially in Indonesia, is associated with at least these three factors: (a) contribution of ecommerce to taxes, (b) e-commerce as the driver of other industry sectors, and (c) e-commerce as the media for micro-small-medium enterprises (MSMEs). The increasing number of online businesses will contribute to taxes. Andriawan (2019) stated that tax issue involves at least three parties, i.e., the business themselves, the marketplace platforms, and the online business vendors in many other media. E-commerce also drives other industry sectors like manufacturing, packaging, transportation, fuel, and finance. Thus, indirectly but sure, e-commerce pulls the contribution to $37.15 \%$ og GDP (Statistics Indonesia, 2021). Related to MSMEs development, e-commerce like virtual marketplace and social media commerce provide simple and economical media for MSMEs to develop their market and business. More than $75 \%$ of e-commerce businesses are micro and small enterprises, and more than $19 \%$ are medium enterprises (Kusumatrisna et al., 2020).

The most popular e-commerce in Indonesia is the virtual marketplace, in which online shops joining and sell their products under marketplace management. Even though e-commerce transactions generally increase yearly (GlobalData, 2020), some online shops operating in marketplaces are not successful. Centerklik (2021) released a statement that about $80 \%$ of online shops are failed. Furthermore, a sampling of sales volume data of some items in a marketplace shows that $80 \%$ of sales is obtained by only $20 \%$ to $40 \%$ of shops. Some unsuccessful online shops last with low sales volume, and others even failed to survive and close their shops. The factors of online shop success are varied, thus. A study of the success factors of online shops is important to be performed, to provide suggestions to online shop business people in managing their shops successfully.

\section{LITERATURE REVIEW}

\subsection{Researches on Online Shop}

According to Kotler et al. (2012), e-commerce is an online business channel that can be accessed through devices like computers or cellphones, in which producers and/or sellers and customers meet each other to do the business. People in business or business administrators use e-commerce to run their business activities, while customers use e-commerce to gain information about products or services to be bought. One of the types of e-commerce is a virtual marketplace. Many shops are joining a marketplace to sell their products. A marketplace manages the shops just like a shopping mall managing the stores and outlets inside it.
There are standard rules that the shops should follow in a marketplace. The way the shops show their merchandise, ordering procedure, payment procedure, warranty policies, and seller-buyer interaction are some of the standard rules mentioned.

As explained in the previous sections, discussion of online shop success factors is beneficial to help online shop practitioners making their business successful. There have been several studies about online shop success factors. According to those studies, the success factors of online shop are: culture and personal factors (Komiak et al., 2008; Malehmir et al., 2017; Febrilia \& Warokka, 2021), shop reputation (Komiak et al., 2008; LeGresley, 2014), transaction policy (Sahney, 2008), buyer-seller interactions (Sahney, 2008; LeGresley, 2014; Shaflee \& Bazargan, 2018), safety and privacy (Sahney, 2008; Chen et al., 2013; LeGresley, 2014; Istiqomah et al., 2017; Shaflee \& Bazargan, 2018), web performance (Saheny, 2008; Chen, 2013; Rouibah, 2014; Shaflee \& Bazargan, 2018; Febrilia \& Warokka, 2021), delivery system (Sahney, 2008), product information (Chen et al., 2013; Devi, 2019; Febrilia \& Warokka, 2021), service quality (Chen et al., 2013; Rouibah, 2014; Malehmir et al., 2017; Shaflee \& Bazargan, 2018), assurance (Komiak et al., 2008; LeGresley, 2014; Shaflee \& Bazargan, 2018), promotion (Mujiyana \& Elissa, 2013; Istiqomah et al., 2017; Devi, 2019; Febrilia \& Warokka, 2021), price (Devi, 2019), and seller performance (Ratnasari, 2017; Malisa, 2020).

The studies mentioned above were mainly conducted by a survey of online shoppers or online shop owners, except LeGresley (2014) and Komiak et al. (2008). LeGresley (2014) did a case-based literature review, while Komiak et al. (2008) took the data from an ecommerce website. Respondents' opinion in a survey has weaknesses in terms of the validity of the responses regarding the subjective conditions of respondents during the survey. The structured questions of the questionnaire also lead the respondents to choose the most appropriate available answer, although the answers are not really reflecting their opinion. The transactionrelated data can be the alternate data to be used, like the observation performed by Komiak et al. (2008).

According to some research, the types and level of information in an online shop's buyer-seller/user interface influence the customer's willingness to buy. The information mainly includes information about products (Maditinos \& Theodoridis, 2010; Guo et al., 2011; Chen et al., 2013; Dai et al., 2014, Hsu \& Tang, 2020; Febrilia \& Warokka, 2021), information about services (Maditinos \& Theodoridis, 2010; Chen et al., 2013; Shaflee \& Bazargan, 2018), and information related to the transaction (Maditinos \& Theodoridis, 2010; Hsu \& Tang, 2020). Thus, information in the user interface of an online shop can persuade customer's decision to buy. In other words, data available in the buyer-seller interface of an online shop can be used to predict the success model of an online shop. How the shop behaves related to product, service, and 
transactions can be correlated to the success attributes of the shop.

The user interface of an online shop is the only medium for customer and seller interaction. Most of the interaction processes are doing asynchronous, except for some chats between buyer and seller when the buyer is available online. Thus, the information available in the user interface will be the reference for the customer to process the shopping activities. Online shop user interface takes all the roles, i.e., as a storefront, shopkeeper, pricelist, cashier, delivery service, and even promotion board. Using the user interface, customers surf the storefront to find product information, select products and stores, ask the seller, make transactions, execute payments, complain, and review. The central role of an online shop user interface encourages the development of studies about the user interface of an online shop since 2005. Some of those studies discuss the design and development of online shop user interface (Hasan, 2013; LeGresley, 2014; Kusumawardani et al., 2017), user interface performance (Souissay et al., 2019; Aziza, 2019; Muqoddas et al., 2020), and the effect of a user interface to the shop success (Maditinos \& Theodoridis, 2010; Chen et al., 2013; Hasan, 2013; Rouibah, 2014; Siagian \& Cahyono, 2014; Kusumawardani et al., 2017; Hsu \& Tang, 2020).

Although there are much data available in online shop user interfaces, researchers that utilize the detailed elements of information in the user interface are still rare. The existing research discusses only some of the elements, mainly related to services aspects, as a study carried out by Komiak et al. (2008). Other data from online shop user interfaces in existing research are the number of buyers, number of visitors, and customer reviews (Komiak et al., 2008; Mouratidis \& Papagiannakis, 2021). Therefore, this study utilizes all of the data available in the online shop user interface, or other words, performs user interface analytics, to develop an online shop success model. The object of this study is online shops operated in a virtual marketplace.

The model developed in this study is basically a relationship model among variables. Many alternative approaches can be applied to develop a model of the relationship among variables, as described in the following researches. Komiak et al. (2008), Rouibah (2014), Istiqomah et al. (2017), Malehmir et al. (2017), Nugroho (2018), Devi (2019), Dong (2020), and Nagoro (2020) use linear regression to model the relationships between some dependent variables of product success and shop success with some variables of success factors. Regarding the usage of binary dependent variables, some research uses a logistic regression model (Nagoro, 2020) or paired t-test (Maditinos \& Theodoridis, 2010; Mouratidis \& Papagiannakis, 2021). Kelvin (2020) and Tamba (2020) utilized the Kano approach to model the relationships between product success attributes and success factor attributes under the assumption that the relationships are not necessarily linear. Structural equation model (SEM) is also applied in some researches, related to the need to include moderating variables and the advantage of simultaneous computation of some measured attributes for every variable (Sahney, 2008; Chen et al., 2013; Dai et al., 2014; Hair Jr. et al., 2014; Shaflee \& Bazargan, 2018; Febrilia \& Warokka, 2021). A probabilistic model is also used to picture the relationships among variables in online business related to the probabilistic behavior of customers (Guo et al., 2011). In connection with the purpose of identifying the contribution of the variables studied, Hsu \& Tang (2020) used the analytic hierarchy process.

\subsection{Conceptual Model}

A lot of data available in the user interface of marketplaces represent the result of the interaction between seller and customer. There are some data items that might be considered by the customer when deciding to buy a product, or in other words, there is information about factors of buying decision. There are also data related to the success of a product or shop. When the product or shop success attributes are correlated to the factors of buying decisions, a predictive model of shop performance factors can be developed.

The user interface observed in this study is owned by one of the top marketplaces operated in Indonesia. Eight data items could be taken from the interface to be the variables for this study. They are product price (X1), percentage of the responded chat (X2), shop joining time in the marketplace (X3), number of product types (X4), number of customers rating the products or number of raters (X5), shop rating (X6), shop reputation (X7), and number of followers (X8). The product price is the relative price of a product in a shop compared to a similar product in other shops. Based on other researches, especially in Indonesia, price is one of the most considered factors of customer decision-to-buy (Nugroho, 2018; Devi, 2019; Nagoro, 2020). The percentage of responded chats shows the sellers' service level, which is definitely related to customer satisfaction. The shop joining time in the marketplace might indirectly affect the customer's decision because it is related to the cumulative number of sold products, making the shop more trusted by the customers. The number of product types is related to the opportunity for customers to choose the item they like, which potentially affects the customer decision. The number of followers represents the attractiveness of a shop according to its customers so that the customers decide to follow the shop always to get the recent updates. The shop rating is a shop performance level given by the customers, with a scale of 0 to 5 , and visualized as the number of stars. It represents the customer satisfaction level on the shop's overall performance, based on customers' shopping experience (Shopee, 2021b). The shop reputation is a shop performance level given by the marketplace management, by which the shops in the marketplace are categorized as star sellers or non-star sellers. The shop reputation is an outcome resulting from the strength of sales record, the level of service, the speed and reliability of order fulfillment, the compliance to marketplace regulation, and the level of the shop and 
product performance (Shopee, 2021a).

The conceptual model developed from the variables as mentioned earlier is illustrated in Figure 1. Variables $\mathrm{X} 1, \mathrm{X} 2, \mathrm{X} 3, \mathrm{X} 4$, and $\mathrm{X} 5$ can be determined as independent variables, as they potentially affect the shop performance. The other three variables, X6, X7, and X8, are more suitable to be defined as dependent variables, as they are presenting the shop performance.

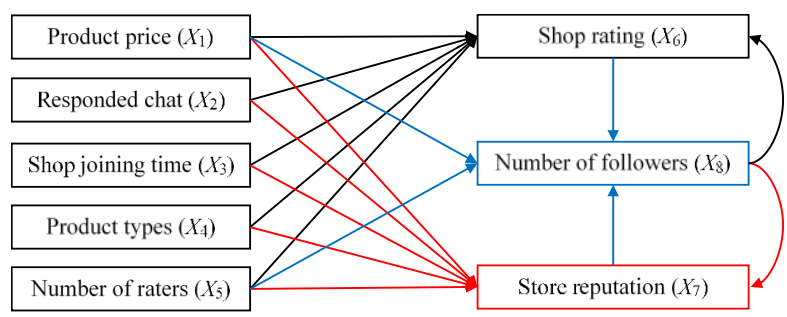

Figure 1. Conceptual relationship model of online shop performance factors

Variables $\mathrm{X} 1, \mathrm{X} 2, \mathrm{X} 3, \mathrm{X} 4$, and $\mathrm{X} 5$ are estimated to influence $\mathrm{X} 6$ and $\mathrm{X} 7$, while $\mathrm{X} 8$ is estimated to be influenced only by variables X1 and X5. The number of followers might be affected directly by product price, as customers usually try to find the cheapest product using filter facilities available in the marketplace. It also can be estimated that the number of followers is affected by the number of raters because both variables are related to customer experiences during the shopping process. Variables X2, X3, and X4 do not directly affect X8, yet their influences manifest through X6 and X7.

Further, variable $\mathrm{X} 8$ can take a role as both independent variable and dependent variables. As an independent variable, X8 affects $\mathrm{X} 6$ and $\mathrm{X} 7$. The number of followers can be affecting the shop rating because a follower must be a customer having a positive perception of the shop. The number of followers affects shop reputation in terms of shop performance parameters measured by marketplace management (Shopee, 2021a). Conversely, X6 and X7 may affect X8, as a customer may be interested in following a shop after noticing the rating and reputation.

As explained in Sub-section 2.1, three possible methods can be used to estimate the relationship among the variables. They are linear regression, Kano approach, and SEM. This study uses linear regression. There is a possibility that the relationship is not linear, and transformation of variables is chosen before the regression, rather than using a non-linear model like Kano. Kano cannot accommodate the need to do multivariate analysis. Figure 1 shows the need to use moderating variables, i.e., those that can take roles as both dependent and independent, like X6, X7, and X8. However, all the variables are directly measured variables. Thus there is no necessity to use SEM. The estimation for the conceptual model will be obtained by three regression models (Model I, Model II, Model III), as only one dependent variable can be included in a regression model. The model I, Model II, and Model III are presented in Equation (1), Equation (2), and Equation (3), respectively.

$$
\begin{aligned}
& X_{6}=\beta_{06}+\beta_{16} X_{1}+\beta_{26} X_{2}+\beta_{36} X_{3}+\beta_{46} X_{4}+\beta_{56} X_{5}+\beta_{86} X_{8} \\
& +e_{6} \\
& X_{7}=\beta_{07}+\beta_{17} X_{1}+\beta_{27} X_{2}+\beta_{37} X_{3}+\beta_{47} X_{4}+\beta_{57} X_{5}+\beta_{87} X_{8} \\
& +e_{7} \\
& X_{8}=\beta_{08}+\beta_{18} X_{1}+\beta_{58} X_{5}+\beta_{68} X_{6}+\beta_{78} X_{7}+e_{8}
\end{aligned}
$$

$\beta_{\mathrm{ij}}$ is unique coefficient for variable $\mathrm{i}$ in model with dependent variable $X_{\mathrm{j}}$, while $e_{\mathrm{j}}$ is unexplained variance of dependent variable $X_{\mathrm{j}}$.

\subsection{Research Questions}

Regarding the eight variables and the conceptual model defined in this study as explained in Sub-section 2.2 , two problems arose, i.e., which variables are really involved in the model and how the variables contribute to the model. In addition, the results of this study will prove if the data available in the online shop user interface can be used to predict the success factors of the online shop and customer behavior behind the data. The following research questions are defined to answer the problems.

$Q_{1}$ : Do $X_{1}, X_{2}, X_{3}, X_{4}, X_{5}$, and $X_{8}$ influence $X_{6}$, and how are their influence?

$Q_{2}$ : Do $X_{1}, X_{2}, X_{3}, X_{4}, X_{5}$, and $X_{8}$ influence $X_{7}$, and how are their influence?

$Q_{3}$ : Do $X_{1}, X_{5}, X_{6}$, and $X_{7}$ influence $X_{8}$, and how are their influence?

$Q_{4}$ : Could the data available in the online shop user interface be utilized to predict the online shop success factors?

These research questions will be answered through a regression process on the data scraped from online shops' user interfaces.

\section{METHODOLOGY}

\subsection{Data Collection}

Data are collected from the user interface of one of the virtual marketplaces operated in Indonesia from February to March 2021 (Shopee, 2021c). A data scraping process is applied using Octoparse software (Octoparse, 2020). The data taken from the scraping process are the values of variables X1, X2, X3, X4, X5, $\mathrm{X} 6, \mathrm{X} 7$, and $\mathrm{X} 6$ related to many products exposed in the display of many online shops in the marketplace. The product categories selected for this study cover functional products (health products, kitchenware, groceries) and innovative products (cellphone accessories, beauty products, shoes, laptops). A massive number of data are scraped, and 1516 data can be collected after a cleaning process.

\subsection{Data Preparation}

The processes performed in data preparation are data cleaning and outlier handling. Data cleaning is dedicated to disposing of incomplete, doubled data, or unexpected 
data. Unexpected data are the data brought in the scraping process. However, they are not part of the defined product categories. The next process is the identification of outliers in the cleaned data. Outliers are identified by calculating the standard normal (z) scores. For a large number of observations (more than 80 observations), a datum is categorized as an outlier if its $\mathrm{z}$ score is out of the range of $-4<\mathrm{z}<4$ (Hair Jr. et al., 2014). The outliers found then are discarded, resulting in 1384 data from 1516 initial data. Table 1 shows the data collected before and after outlier disposal for every product category.

Table 1. Data collected before and after outlier disposal

\begin{tabular}{|c|l|c|c|}
\hline No. & Product category & \multicolumn{2}{|c|}{ Number of data } \\
\cline { 3 - 4 } & & Initial & $\begin{array}{c}\text { After } \\
\text { outliers } \\
\text { disposal }\end{array}$ \\
\hline 1 & Health product & 109 & 103 \\
\hline 2 & Cellphone accessories & 213 & 200 \\
\hline 3 & Beauty product & 248 & 235 \\
\hline 4 & Shoes & 250 & 229 \\
\hline 5 & Laptop & 75 & 69 \\
\hline 6 & Kitchenware & 250 & 223 \\
\hline 7 & Groceries & 371 & 332 \\
\hline & Total & 1516 & 1384 \\
\hline
\end{tabular}

\subsection{Assumption Tests}

Regression analysis can be applied under the assumption that the variates are normally distributed. All the dependent variables are homoscedastic across all the related dependent variables. The independent variables have linear relationships with the independent variables, and no multicollinearity occurs among the independent variables.

The normality test is performed by calculating the standard normal value of skewness ( $\left.z_{\text {skewness }}\right)$ and kurtosis $\left(z_{\text {kurtosis }}\right)$ of every variable, which should be in the range of $-2.58<z_{\text {skewness }}<2.58$ and $-2.58<z_{\text {kurtosis }}$ $<2.58$ (Hair Jr. et al., 2014). Homoscedasticity and linearity are usually resolved by treating non-normality conditions. For a large number of observations (more than 200), the normality condition represents the homoscedasticity and the linearity as well (Hair Jr. et al., 2014).

Altogether with the results of the homoscedasticity test and linearity test, the non-normal distributed variables should be transformed using power. For example, a non-normally distributed variable $X_{\mathrm{i}}$ will be transformed to $X_{\mathrm{i}}^{\mathrm{a}}$ so that the skewness and kurtosis of $X_{\mathrm{i}}^{\mathrm{a}}$ are satisfied the requirements. The value of power can be searched manually using trial and error or with the help of statistical software like SPSS (IBM, 2021). Some independent variables should be transformed, and the transformed variables resulted for every product category are shown in Table 2. $X_{\mathrm{i} \text { (trans) }}$ is the transformation of variable $X_{\mathrm{i}}$ to replace the related $X_{\mathrm{i}}$ in the models.

Table 2. Transformed variables

\begin{tabular}{|c|c|c|c|c|}
\hline Model & Product category & Dependent & $X_{\mathrm{i}}$ & $X_{\mathbf{i}(\text { trans) }}$ \\
\hline \multirow[t]{2}{*}{ I } & Beauty product & \multirow[t]{2}{*}{$X_{6}$} & $X_{1}$ & $X_{1}^{2}$ \\
\hline & Overall & & $X_{1} ; X_{2} ; X_{5}$ & $X_{1}^{0.2} ; X_{2}^{4} ; X_{5}^{0.2}$ \\
\hline \multirow[t]{6}{*}{ II } & Cellphone accessories & \multirow[t]{6}{*}{$X_{7}$} & $X_{4}$ & $X_{4}^{0.1}$ \\
\hline & Beauty product & & $X_{2} ; X_{8}$ & $X_{2}^{8} ; X_{8}^{0.3}$ \\
\hline & Laptop & & $X_{2} ; X_{5} ; X_{8}$ & $X_{2}^{0.5} ; X_{5}^{0.1} ; X_{8}^{0.5}$ \\
\hline & Kitchenware & & $X_{4}$ & $X_{4}^{0.1}$ \\
\hline & Groceries & & $X_{2} ; X_{4}$ & $X_{2}{ }^{10} ; X_{4}{ }^{0.1}$ \\
\hline & Overall & & $X_{2} ; X_{4} ; X_{5} ; X_{8}$ & $X_{2}{ }^{5} ; X_{4}^{0.1} ; X_{5}^{0.2} ; X_{8}^{0.1}$ \\
\hline \multirow[t]{7}{*}{ III } & Health product & \multirow[t]{7}{*}{$X_{8}$} & $X_{5} ; X_{7}$ & $X_{5}^{0.1} ; X_{7}^{5}$ \\
\hline & Beauty product & & $X_{5}$ & $X_{5}^{0.5}$ \\
\hline & Shoes & & $X_{5}$ & $X_{5}^{0.1}$ \\
\hline & Laptop & & $X_{5}$ & $X_{5}^{0.1}$ \\
\hline & Kitchenware & & $X_{5}$ & $X_{5}^{5}$ \\
\hline & Groceries & & $X_{5}$ & $X_{5}^{5}$ \\
\hline & Overall & & $X_{5}$ & $X_{5}^{0.1}$ \\
\hline
\end{tabular}


The multicollinearity test is intended to ascertain that the variances of all the independent variables are independent of one to another; thus, the contribution of every independent variable to the related dependent variable can be explained. The multicollinearity of some variables will resonate with their errors and attenuate the model's power (Hair Jr. et al., 2014). The parameters to justify the collinearity condition are (a) tolerance value, which should not be more than 0.1 , and (b) variance inflation factors (VIF) which should not be more than 10. The multicollinearity test applied to the transformed variables shows that there is no multicollinearity among them.

\section{RESULTS}

\subsection{The relationship between shop rating and its factors}

The relationship between shop rating (X6) and its factors (product price, X1; percentage of responded chat, X2; shop joining time, X3; the number of product types, $\mathrm{X} 4$; the number of raters, $\mathrm{X} 5$; and the number of followers, X8) presented by Model I in Equation (1), is estimated using linear regression on the data of every product category, as well as on overall data, to answer research question Q1. Table 3 presents the results of the estimates after the transformed variables are re- transformed back to the initial variables. The blank cells indicate that there is no relationship model resulted from the stepwise regression process.

Table 3 shows that there are two feasible models, i.e., the relationship between shop rating and its factors of shoe category and overall products. The other models are not feasible, as the values of the coefficient of determinations $\left(R^{2}\right)$ are less than the minimum values required (Hair Jr. et al., 2014). For the shoe category, product price is the only influential factor for customers to appreciating the shop. The unique phenomenon is that the higher the price, the higher the appreciation from the customer to the shop. The possible reason is that shoes are innovative products, and customers are more attracted by the innovation or quality of the shoes than its price.

There are four influential factors for all products in general, i.e., product price, percentage of responded chat, shop joining time, and the number of raters. The effect of product price is normal, i.e., customers' appreciation increases by decreasing the price. The percentage of responded chat and the number of raters positively influence the shop rating. The shop joining time negatively influences the shop rating, or in other words, new shops are more appreciated by the customers.

Table 3. Estimates of Model I

\begin{tabular}{|l|c|c|c|}
\hline \multicolumn{1}{|c|}{ Product } & Estimates of $X_{\mathbf{6}}$ & \multicolumn{2}{c|}{$\boldsymbol{R}^{\mathbf{2}}$} \\
\cline { 2 - 4 } & & Calc.*** & Min.**** \\
\hline Health product & & 0.04 & 0.17 \\
\hline Cellphone accessories & $X_{6}=22.01+0.26 X_{2}$ & 0.10 \\
\hline Beauty product & $X_{6}=22.50+0.41 X_{1}{ }^{2}$ & 0.05 & 0.08 \\
\hline Shoes & $X_{6}=87.05+6.24 X_{1}$ & $0.09 *$ & 0.09 \\
\hline Laptop & $X_{6}=4.94-1.01 X_{1}$ & 0.15 & 0.25 \\
\hline Kitchenware & & & 0.09 \\
\hline Groceries & & 0.06 \\
\hline Overall & $X_{6}=114.70-1.99 X_{1}{ }^{0.2}+1.88 X_{2}{ }^{4}-1.24 X_{3}+2.35 X_{5}{ }^{0.2}$ & $0.02 *$ & 0.02 \\
\hline
\end{tabular}

*significant at $\mathrm{p}=0.05 ; * *$ calculated; $* * *$ minimum (Hair Jr. et al., 2014)

Table 4. Estimates of Model II

\begin{tabular}{|l|c|c|c|}
\hline \multicolumn{1}{|c|}{ Product } & Estimates of $X_{7}$ & \multicolumn{2}{c|}{$\boldsymbol{R}^{\mathbf{2}}$} \\
\cline { 2 - 4 } & & Calc. $^{* *}$ & Min. $^{* * *}$ \\
\hline Health product & $X_{7}=-0.09+0.91 X_{8}$ & 0.04 & 0.17 \\
\hline Cellphone accessories & $X_{7}=-10.14+0.90 X_{3}+11.09 X_{4}{ }^{0.1}$ & $0.25^{*}$ & 0.10 \\
\hline Beauty product & $X_{7}=-0.36+0.02 X_{2}{ }^{8}+0.01 X_{8}{ }^{0.3}$ & $0.12^{*}$ & 0.08 \\
\hline Shoes & & & 0.09 \\
\hline Laptop & $X_{7}=-24.44+6.67 X_{2}^{0.5}+12.07 X_{5}^{0.1}-0.07 X_{8}^{0.5}$ & 0.18 & 0.25 \\
\hline Kitchenware & $X_{7}=4.14-0.31 X_{1}-0.04 X_{4}^{0.1}$ & 0.08 & 0.09 \\
\hline Groceries & $X_{7}=-8.41+0.57 X_{1}-0.00 X_{2}{ }^{10}+9.27 X_{4}{ }^{0.1}$ & $0.08^{*}$ & 0.06 \\
\hline Overall & $X_{7}=2.27+0.00 X_{2}{ }^{5}-5.16 X_{4}{ }^{0.1}+3.95 X_{5}{ }^{0.2}-0.11 X_{8}{ }^{0.1}$ & $0.05^{*}$ & 0.02 \\
\hline
\end{tabular}

*significant at $\mathrm{p}=0.05 ; * *$ calculated; $* * *$ minimum (Hair Jr. et al., 2014) 


\subsection{The relationship between shop reputation and its factors}

Similar to Sub-section 4.1, in order to answer research question $Q_{2}$, the relationship between shop reputation $\left(X_{7}\right)$ and its factors (product price, $X_{1}$; percentage of responded chat, $X_{2}$; shop joining time, $X_{3}$; the number of product types, $X_{4}$; the number of raters, $X_{5}$; and the number of followers, $X_{8}$ ) presented by Model II in Equation (2), is estimated using linear regression on the data of every product category, as well as on overall data. Table 4 shows the results of the regression.

There are four feasible models in Table 4, i.e., models for cellphone accessories, beauty products, groceries, and overall products. The reputation of cellphone accessories shops is strongly influenced by the shop joining time and number of product types. Thus, the customers of cellphone accessories prefer to buy in a well-established shop that has many product variants. It is different from the reputation of a beauty product shop that tends to be affected by the percentage of responded chat and number of raters. In other words, customers of beauty products are satisfied when they get a good response from the seller and tend to learn from the experience of other customers. The power of 8 of the percentage of responded chat shows that the customers are sensitive to the service level of the shop.

Groceries category gives different findings. The groceries shop's reputation depends on product price and the number of product types. However, unlike the general phenomenon, a higher price makes the shop rating higher in this model. The reason could be explained is that the price of groceries is not so varied. Thus the customers are not really concern about it. However, a deeper study is suggested to get a more precise explanation of this phenomenon. A variable percentage of responded chat appears in the model, but the coefficient is nearly zero, so the effect can be ignored. Groceries are basically standard goods for daily needs; thus, its customers do not require intense communication with the sellers. They just particularly need to get many options of goods to be chosen.
In general, shop reputation is influenced positively by the percentage of responded chat and the number of raters. It is influenced negatively by the number of product types and the number of followers. Thus, in general, customers need to get good responses from the seller and learn from other customers' experiences to decide to buy from a shop. Many options of product and the number of followers are not necessary to be considered by the customers to shop.

\subsection{The relationship between the number of followers and its factors}

The last model is the relationship between the number of followers $\left(X_{8}\right)$ and its factors (product price, $X_{1}$; the number of raters, $X_{5}$; shop rating, $X_{6}$; and shop reputation, $X_{7}$ ), as presented by Model III in Equation (3), to answer research question $Q_{3}$. The linear regression model of every product category and overall data are presented in Table 5.

As listed in Table 5, the feasible models of the relationship between the number of followers and its factors are related to health products, beauty products, groceries, and overall products. In general, as presented by the model for overall products, product price and shop reputation have negative influences on the number of followers. In contrast, the number of raters strongly affects the number of followers. It means that customers' decision to follow a shop is affected by product price and other customers' experience more than shop reputation.

For the health product category, the number of followers is very strongly affected by the number of raters and shop reputation. The power of 5 in the shop reputation variable indicates the concern of customers to choose the best quality of health products and to keep the connection with the chosen shops by following them. It can be caused by the COVID-19 pandemic situation, as the data are taken from February to March 2021, when the first cases of COVID-19 infection were found in Indonesia.

Table 5. Estimates of Model III

\begin{tabular}{|l|c|c|c|}
\hline \multirow{2}{*}{ Product } & Estimates of $X_{8}$ & \multicolumn{2}{c|}{$R^{2}$} \\
\cline { 2 - 4 } & & Calc.** & Min.*** \\
\hline Health product & $X_{8}=-10.29+11.36 X_{5}{ }^{0.1}+0.05 X_{7}^{5}$ & $0.43^{*}$ & 0.15 \\
\hline Cellphone accessories & & & 0.09 \\
\hline Beauty product & $X_{8}=-6.63+7.63 X_{5}{ }^{0.5}$ & $0.51^{*}$ & 0.07 \\
\hline Shoes & $X_{8}=-9.43+10.89 X_{5}^{0.1}$ & 0.07 & 0.08 \\
\hline Laptop & $X_{8}=-1.65+2.79 X_{5}^{0.1}-0.04 X_{7}$ & 0.20 & 0.22 \\
\hline Kitchenware & $X_{8}=1.12+0.00 X_{5}^{5}$ & 0.03 & 0.08 \\
\hline Groceries & $X_{8}=0.94+0.03 X_{1}+0.05 X_{5}^{5}$ & $0.05 *$ & 0.05 \\
\hline Overall & $X_{8}=-7.01-0.04 X_{1}+8.27 X_{5}{ }^{0.1}-0.02 X_{7}$ & $0.13^{*}$ & 0.01 \\
\hline
\end{tabular}

*significant at $\mathrm{p}=0.05$; **calculated; ***minimum (Hair Jr. et al., 2014) 
As listed in Table 5, the feasible models of the relationship between the number of followers and its factors are related to health products, beauty products, groceries, and overall products. In general, as presented by the model for overall products, product price and shop reputation give negative influences on the number of followers. In contrast, the number of raters strongly affects the number of followers. It means that customers' decision to follow a shop is affected by product price and other customers' experience more than shop reputation.

For the health product category, the number of followers is very strongly affected by the number of raters and shop reputation. The power of 5 in the shop reputation variable indicates the concern of customers to choose the best quality of health products and to keep the connection with the chosen shops by following them. It can be caused by the COVID-19 pandemic situation, as the data are taken from February to March 2021, when the first cases of COVID-19 infection were found in Indonesia.

As shown by the second feasible model listed in Table 5 , customers of the beauty product category are strongly affected by the number of raters, or in other words, the other customers' experience, to follow a shop. It is in line with the related result of Model II in Sub-section 4.2 .

The number of followers is in line with the product price and the number of raters for the groceries category. The effect of product price is similar to the result of Model II on Sub-section 4.2, i.e., the price of groceries is not so varied and does not become the customers' interest. The effect of the number of raters is stronger than the effect of the product price, although the model as a whole is actually not a strong model, as the $R^{2}$ is just the same with the minimum required value.

\section{DISCUSSIONS}

Model I, Model II, and Model III are the parts of a model presented in Figure 1. From those models, some general insights can be summarized for every product category and overall products, as presented in Table 6 . The checked marks $(\checkmark)$ are put in the cells if: (a) the variable shown in the column significantly influences at least one of the performance (dependent) variables used in Model I (shop rating), Model II (shop reputation), or Model III (number of followers); (b) the influences are not contradictory (positive in one model while negative in another model). The blocked cells indicate negative influences.

Table 6 shows that, in general, the shop rating is completely a dependent variable, whereas the shop's reputation and the number of followers can be dependent or independent variables. The number of raters becomes the most influencing variable, followed by product price, percentage of responded chat, and the number of product types.

For overall products, the product price, the shop joining time in the marketplace, the number of product types, the shop reputation, and the number of followers are the variables providing negative effects on shop performance. It means that the performance of an online shop is high if the price of the products sold is low, the shop is new, the shop focuses on a certain product type, no matter the reputation and the number of followers. The other two variables, i.e., the percentage of responded chat and the number of raters, positively affect the shop performance. Thus, to be successful, online shop sellers should be responsive to their customers while encouraging the customers to rate their shop. Figure 2 shows how the conceptual model in Figure 1 is modified to illustrate this general relationship model.

Table 6. Summary of the insights related to product category

\begin{tabular}{|l|c|c|c|c|c|c|c|c|c|}
\hline \multicolumn{1}{|c|}{ Product category } & \multicolumn{2}{c|}{$\begin{array}{c}\text { Performance } \\
\text { variables }\end{array}$} & \multicolumn{5}{c|}{ Influential variables } \\
\hline & & $X_{\mathbf{1}}$ & $\boldsymbol{X}_{\mathbf{2}}$ & $\boldsymbol{X}_{\mathbf{3}}$ & $\boldsymbol{X}_{\mathbf{4}}$ & $\boldsymbol{X}_{\mathbf{5}}$ & $\boldsymbol{X}_{\mathbf{6}}$ & $\boldsymbol{X}_{\mathbf{7}}$ & $\boldsymbol{X}_{\mathbf{8}}$ \\
\hline Health product & $X_{8}$ & & & & & $\checkmark$ & & $\checkmark$ & \\
\hline Cellphone accessories & $X_{7} ; X_{8}$ & & $\checkmark$ & & & $\checkmark$ & & & $\checkmark$ \\
\hline Beauty product & $X_{6}$ & $\checkmark$ & & & & & & & \\
\hline Shoes & & & & & & & & & \\
\hline Laptop & & & & & & & & & \\
\hline Kitchenware & $X_{7} ; X_{8}$ & $\checkmark$ & & & $\checkmark$ & $\checkmark$ & & & \\
\hline Groceries & $X_{6} ; X_{7} ; X_{8}$ & & $\checkmark$ & & & $\checkmark$ & & & \\
\hline Overall & & & & $\checkmark$ & $\checkmark$ & & & & \\
\hline
\end{tabular}




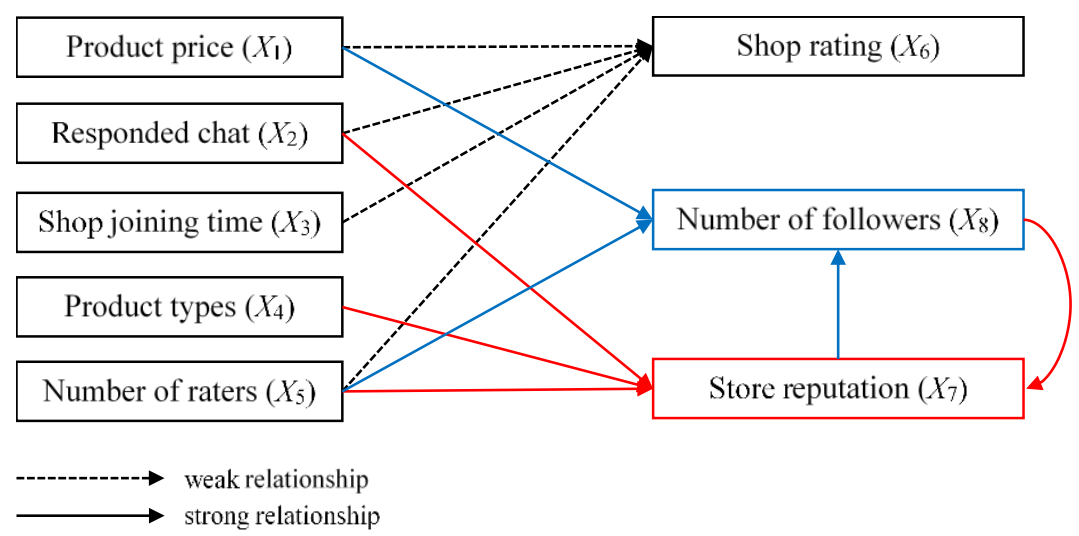

Figure 2. Model of online shop performance factors for all product categories
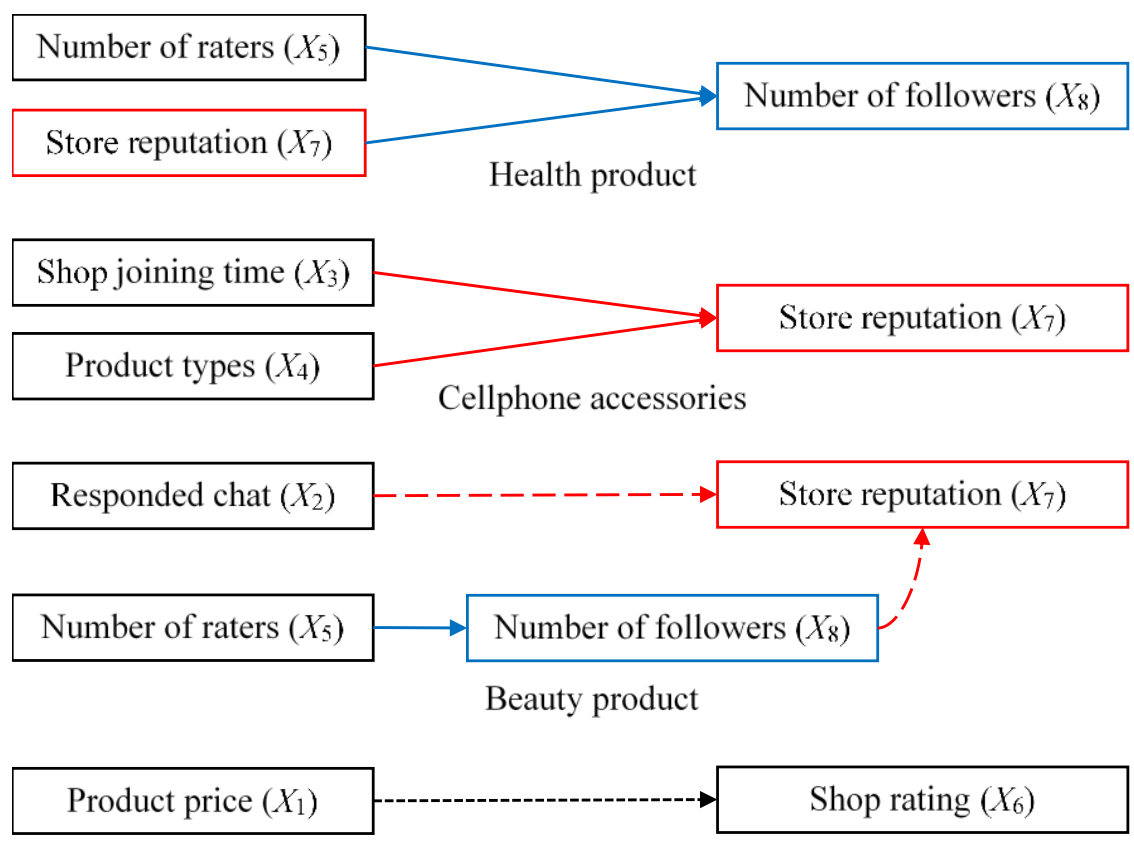

Shoes

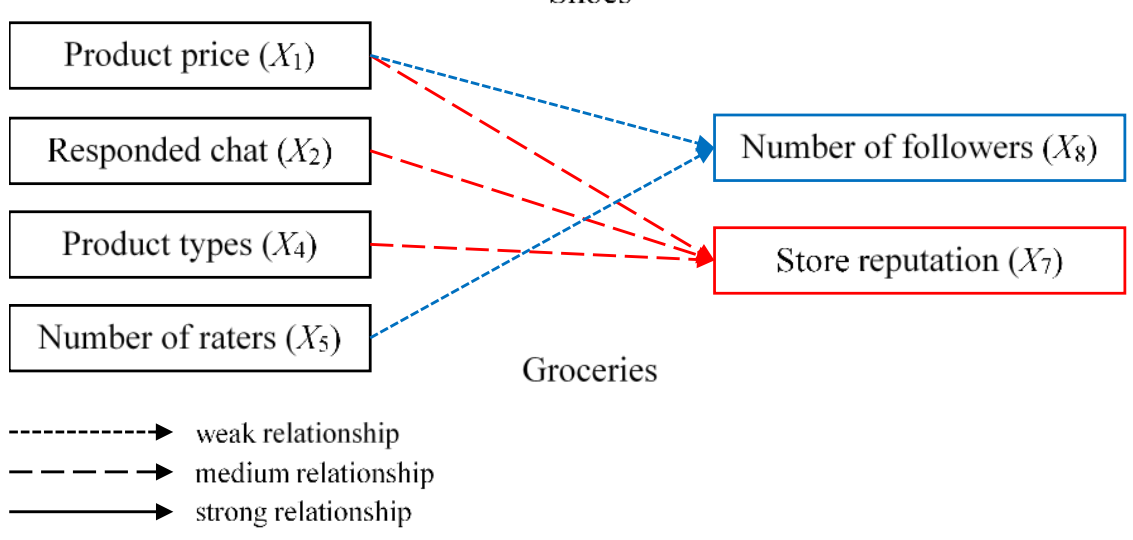

Figure 3. Model of online shop performance factors for every product category 
Even though a general model can be constructed, specific models for the laptop category and kitchenware category cannot be explained yet based on the data collected in this study. It can be caused by the small number of observations, especially related to the laptop category, or because both categories are highly innovative products. Hence, the customers are unaware of the price, seller's response, shop condition, or shop image. The good searching facilities are sufficient for customers to find the product they want.

The summary shown in Table 6 and Figure 3 can be used as a guide for online shop sellers. Depends on what kind of products they sell, the sellers can develop or improve their strategy to increase the shop performance. For instance, an online shop selling health products must pay intention to encourage its customer to rate the shop and to develop their reputation. If the shop wants to extend the product types by beauty product, the shop has to increase the responsiveness to the customers while encouraging them to follow the shop.

Summarily, the insights raised from the results of this study as presented in Table 3 to Table 6, Figure 2, and Figure 3 provide proof that user interface analytics can be the basis for the development of a predicted model of online shop performance. It answers research question $Q_{4}$. This study shows that the data recorded and shown in the online user interface in a marketplace can illustrate the phenomena of the processes mediated by the marketplace system. Moreover, the behavior of the parties involved in the processes, i.e., the sellers and the customers, can also be predicted.

\section{CONCLUSION AND FURTHER STUDY}

This study determines eight variables to develop a conceptual model of the relationship between online shop performance and some factors. The variables are defined based on the data scraped from the online shops' user interface in a marketplace. They are: product price, percentage of responded chat, shop joining time in the marketplace, number of product types, number of raters, shop rating, shop reputation, and number of followers.

The conceptual model is then tested using regression analyses, and the results show that the model estimates are specific for every product category sold in the online shop. From the seven product categories observed, the models of two of them, i.e., laptop and kitchenware, cannot be explained. In general, the online shop performance is negatively affected by the product price, the shop joining time, the number of product types, the shop reputation, and the number of followers. Besides, the online shop performance is positively influenced by the percentage of responded chat and the number of raters.

The model developed in this study can be used as a guide by online shop practitioners to decide the appropriate strategy in selling their products. Instead of giving efforts for all aspects, they can just focus on specific aspects related to their product categories. The results of this study also prove that user interface analytics is effective in estimating the performance factors of online shops in a marketplace. These findings are important to be the basis of future studies. Extended data from other e-marketplaces and other product categories can be analyzed to get a general conclusion. Different marketplaces, different countries, and different times of data taking are interesting to be explored, as the previous researches on customer behavior show that location, culture, and time make differences (Komiak et al., 2008; Sahney, 2008; Malehmir et al., 2017; Febrilia \& Warokka, 2021).

Moreover, a similar concept, i.e., user interface analytics, can be applied to other e-commerce systems and digital applications to learn any phenomena that are possibly related to the available data. Hotel reservation systems, consultant websites, lecture management systems are some possible objects that could be mentioned to implement user interface analytics. With the explosion and massive use of information systems and digital applications today and in the future, utilizing available big data is likely preferred over giving the effort to take new data.

\section{ACKNOWLEDGMENT}

We thank Andika Jati Nugroho, Christin Margaretta Tamba, Evita Mareline Nagoro, and Kelvin (Alumni of Industrial Engineering Department, Universitas Atma Jaya Yogyakarta) for contributing their research data to this study. We also thank The Directorate of Research and Community Service, Ministry of Education, Culture, Research, and Technology/National Research and Innovation Body of the Republic of Indonesia for the financial support.

\section{REFERENCES}

Andriawan, F. (2019, January 14). Aturan pajak ecommerce: Bagaimana dampaknya ke bisnis online? Paper Blog, Berita dan Event UMKM. Accessed on May 26, 2020 from https://www.paper.id/blog/beritaacara-umkm/aturan-pajak-ecommerce/

Aziza, R.F.A. (2019). Analisa usability desain user interface pada website Tokopedia menggunakan metode heuristics evaluation. Jurnal Tekno Kompak, 13(1), 7-11.

Brewer, P., \& Sebby, A.G. (2021). The effect of online restaurant menus on consumers' purchase intentions during the COVID-19 pandemic. International Journal of Hospitality Management, 94, 1-9.

Centerklik $^{\mathrm{TM}}$. (2021). 8 Alasan mengapa bisnis online Anda gagal. Centerklik. Accessed on September 10, 2021 from https://www.centerklik.com/alasan-bisnistoko-online-gagal/

Chang, T.Y., Hsu, M.L., Kwon, J.S., Kusdhany, M.L.S., \& Hong, G. (2021). Effect of online learning for dental education in Asia during the pandemic of COVID-19. Journal of Dental Sciences, in press. 
Chen, J.V., Rhungrhuengsamrit, D., Rajkumar, T.M., \& Yen, D.C. (2013). Success of electronic commerce web sites: A comparative study in two countries. Information \& Management, 50(6), 344-355.

Dai, B., Forsythe, S., \& Kwon, W.S. (2014). The impact of online shopping experience on risk perceptions and online purchase intentions: Does product category matter? Journal of Electronic Commerce Research, 15(1), 13-24.

Dannenberg, P., Fuchs, M., Riedler, T., \& Wiedemann, C. (2020). Digital transition by Covid- 19 pandemic? The German food online retail. Tijdschrift voor Economische en Sociale Geografie, 111(3), 543-560.

Devi, L.K.I. (2019). Pengaruh kualitas produk, harga dan promosi terhadap keputusan pembelian pada marketplace Shopee: Studi kasus pada mahasiswa di Surabaya (Doctoral dissertation, UIN Sunan Ampel, Surabaya).

Dong, J., Chen, Y., Gu, A., Chen, J., Li, L., Chen, Q., Li., S. \& Xun, Q. (2020). Potential trend for online shopping data based on the linear regression and sentiment analysis. Mathematical Problems in Engineering, 2020, 4591260.

Elseoud, M.S.A. (2014). Electronic commerce and economic growth in Saudi Arabia. International Journal of Economics Commerce and Management, 2(5), 1-16.

Falk, M. \& Hagsten, E. (2015). E-commerce trends and impacts across Europe. International Journal of Production Economics, 170(A), 357-369.

Febrilia, I. \& Warokka, A. (2021). Consumer traits and situational factors: Exploring the consumer's online impulse buying in the pandemic time. Social Sciences \& Humanities Open, 4(1), 1-8.

GlobalData, Plc. (2020). Indonesia's e-commerce market continues to surge amid COVID-19 pandemic, says GlobalData. Global Data, Plc., Banking. Accessed on July 24, 2021 from https://www.globaldata.com/indonesias-e-commercemarket-continues-surge-amid-covid-19-pandemicsays-globaldata/

Guo, S., Wang, M., \& Leskovec, J. (2011, June 5-9). The role of social networks in online shopping: Information passing, price of trust, and consumer choice. Proceedings of the $12^{\text {th }}$ ACM Conference on Electronic Commerce, 157-166.

Hair Jr., J.F., Black, W.C., Babin, B.J., \& Anderson, R.E. (2014). Multivariate data analysis ( $7^{\text {th }}$ ed.). Harlow, England: Pearson Education, Ltd.

Hasan, S.R. (2013). Developing an online store for a startup apparel business [Bachelor thesis, Business Information Technology, Haaga-Helia University of Applied Sciences, Helsinki].

Hsu, T. \& Tang, J. (2020). Development of hierarchical structure and analytical model of key factors for mobile app stickiness. Journal of Innovation \& Knowledge, 5(1), 68-79.

IBM. (2021). IBM SPSS software. Accessed on April, 2021 from https://www.ibm.com/analytics/spssstatistics-software

Istiqomah, I., Hidayat, Z., \& Jariah, A. (2019, July 6). Analisis pengaruh kepercayaan, iklan dan persepsi resiko terhadap keputusan pembelian di situs Shopee di Kota Lumajang. Proceedings of Progress Conference, 2(1), 557-563.

Kelvin. (2020). Usulan strategi peningkatan kesuksesan produk inovatif dengan model Kano berdasarkan informasi pada antarmuka e-marketplace (Undergraduate thesis, Industrial Engineering Department, Universitas Atma Jaya Yogyakarta, Yogyakarta).

Kementerian Hukum dan HAM RI. (2017). Peta Jalan Sistem Perdagangan Nasional Berbasis Elektronik (Road Map E-Commerce) Tahun 2017-2019. Accessed on July 24, 2021 from https://peraturan.go.id/common/dokumen/ln/2017/ps 74-2017.pdf

Komiak, P., Komiak, S.Y.X., \& Imhof, M. (2008). Conducting international business at eBay: The determinants of success of e-stores. Electronic Markets, 18(2), 187-204.

Kotler, P., Armstrong, G., \& Opresnik, M.O. (2018). Principles of marketing (17 ${ }^{\text {th }}$ ed.). Harlow, England: Pearson Education, Ltd.

Kusumatrisna, A.L., Rosama, N.A., Syakilah, A., Wulandari, V.C., Untari, R., \& Sutarsih, T. (2020). Statistik E-Commerce 2020. Statistics Indonesia, Catalog No. 8101004.

Kusumawardani, A., Rusli, M., \& Rani, E.S. (2017). Pengembangan web online shop pada butik Azzalea Store. Kalbiscientia Jurnal Sains dan Teknologi, 4(2), 49-59.

LeGresley, B. (2014). Trust: A key success factor in the online retail industry [Master thesis, Faculty of Business Administration, Simon Fraser University, Burnaby].

Liu, S. (2013, June 8-9). An empirical study on ecommerce's effect on economic growth. Proceedings of the 2013 International Conference on Education Technology and Management Science (ICETMS 2013), 81-84.

Maditinos, D.I. \& Theodoridis, K. (2010). Satisfaction determinants in the Greek online shopping context. Information Technology \& People, 23(4), 312-329.

Malehmir, F., Maeen, M., \& Jahangir, M.R. (2017). A study on the interaction of motivations and online shopping experience in e-commerce success in Digikala Company. International Journal of Scientific 
Study, 5(5), 180-185.

Malisa, A.N. (2020). Analisis faktor penyebab kegagalan bisnis online: Studi pada mahasiswa Fakultas Ekonomi dan Bisnis Islam Universitas Islam Negeri Sunan Ampel Surabaya (Doctoral dissertation, UIN Sunan Ampel, Surabaya).

Mouratidis, K. \& Papagiannakis, A. (2021). COVID-19, internet, and mobility: The rise of telework, telehealth, e-learning, and e-shopping. Sustainable Cities and Society, 74, 103182.

Mujiyana, M., \& Elissa, I. (2013). Analisis faktor-faktor yang mempengaruhi keputusan pembelian via internet pada toko online. J@ti Undip: Jurnal Teknik Industri, 8(3), 143-152.

Muqoddas, A., Yogananti, A.F., \& Bastian, H. (2020). Usability User Interface Desain pada Aplikasi Ecommerce (Studi Komparasi Terhadap Pengalaman Pengguna Shopee, Lazada, dan Tokopedia). Andharupa: Jurnal Desain Komunikasi Visual \& Multimedia, 6(1), 73-82.

Nagoro, E.M. (2020). Usulan perbaikan pengelolaan toko online di marketplace berdasarkan identifikasi faktor sukses dari informasi pada antarmuka marketplace (Undergraduate thesis, Industrial Engineering Department, Universitas Atma Jaya Yogyakarta, Yogyakarta).

Nugroho, A.J. (2018). Faktor-faktor yang berpengaruh pada kesuksesan produk dan toko online di Tokopedia (Undergraduate thesis, Industrial Engineering Department, Universitas Atma Jaya Yogyakarta, Yogyakarta).

Octoparse. (2020). Easy Web Scraping for Anyone. Octopus Data, Inc. Accessed on February-March, 2021 from https://www.octoparse.com/

Qu, L., \& Chen, Y. (2014). The impact of e-commerce on China's economic growth. WHICEB 2014 Proceedings, 101.

Ratnasari, A.D. (2017). Analisis faktor-faktor yang mempengaruhi keberhasilan usaha bisnis online shop di Kota Samarinda. Jurnal Administrasi Bisnis, 5(1), 122-124.

Rouibah, K. (2014, January 7-9). E-shopping success dimensions: An empirical study in Kuwait. Proceedings of the 2014 International Conference on Industrial Engineering and Operations Management. 948-958.

Sahney, S. (2008). Critical success factors in online retail: An application of Quality Function Deployment and Interpretive Structural Modeling. International Journal of Business and Information, 3(1), 144-163.

Sanchez-Diaz, I., Vural, C.A., \& Halldórsson, Á. (2021). Assessing the inequalities in access to online delivery services and the way COVID-19 pandemic affects marginalization. Transport Policy, 109, 24-36.

Shaflee, M.M. \& Bazargan, N.A. (2018). Behavioral customer loyalty in online shopping: The role of eservice quality and e-recovery. Journal of Theoretical and Applied Electronic Commerce Research, 13(1), 26-38.

Sharma, A., Adhikary, A., \& Borah, S.B. (2020). Covid19's impact on supply chain decisions: Strategic insights from NASDAQ 100 firms using Twitter data. Journal of Business Research, 117, 443-449.

Shopee. (2021a). Menjadi Penjual Star Shopee. Shopee: Program Star Shopee. Accessed on July 26, 2021 from

Shopee. (2021b). Product and shop ratings. Shopee: Customer satisfaction. Accessed on July 26, 2021 from https://seller.shopee.com.my/edu/article/315

Shopee. (2021c). Product catalogue. Shopee. Accessed on February-March, 2021 from https://shopee.co.id/

Siagian, H. dan Cahyono, E. (2014). Analisis website quality, trust dan loyalty pelanggan online shop. Jurnal Manajemen Pemasaran, 8(2), 55-61.

Souissay, V.S., Rokhmawati, R.I., \& Az-Zahra, H.M. (2019). Perbaikan user interface dan analisis perbandingan hasil pada website Lazada.co.id dengan menggunakan usability testing dan system usability scale (SUS) questionnaire. Jurnal Pengembangan Teknologi Informasi dan Ilmu Komputer, 3(4), 35053512.

Statista (2021b). Number of internet users in Indonesia from 2015 to 2025. Statista: Statistics. Accessed on July 24, 2021 from https://www.statista.com/statistics/254456/numberof-internet-users-in-indonesia/

Statista. (2021a). Number of internet users in the Asia Pacific region as of January 2021, by country. Statista: Statistics. Accessed on July 24, 2021 from https://www.statista.com/statistics/265153/numberof-internet-users-in-the-asia-pacific-region/

Statistics Indonesia. (2021). [2010 Version] GDP at 2010 Version (Billion Rupiahs), 2021. Accessed on July 24, 2021 from https://www.bps.go.id/indicator/11/65/1/-2010version-gdp-at-2010-version.html

Tamba, C.M. (2020). Usulan strategi penigkatan kesuksesan produk bagi pelaku bisnis produk fungsional berdasarkan informasi pada antarmuka marketplace (Undergraduate thesis, Industrial Engineering Department, Universitas Atma Jaya Yogyakarta, Yogyakarta). 